\title{
Stereotactic radiotherapy for the treatment of pulmonary metastases: a narrative review
}

\author{
Angelo Tozzi, Ilaria Meaglia, Luca Trapani, Giovanni Battista Ivaldi^ \\ Department of Radiation Oncology, ICS Maugeri SpA SB-IRCCS, Pavia, Italy \\ Contributions: (I) Conception and design: A Tozzi, GB Ivaldi; (II) Administrative support: I Meaglia, L Trapani; (III) Provision of study materials \\ or patients: All authors; (IV) Collection and assembly of data: I Meaglia; (V) Data analysis and interpretation: A Tozzi, I Meaglia, GB Ivaldi; (VI) \\ Manuscript writing: All authors; (VII) Final approval of manuscript: All authors. \\ Correspondence to: Giovanni Battista Ivaldi. Department of Radiation Oncology, ICS Maugeri SpA SB-IRCCS, Pavia 27100, Italy. \\ Email: giovannibattista.ivaldi@icsmaugeri.it.
}

\begin{abstract}
Objective: To describe the rationale and the technique summarizing the most recent and relevant results reported in the scientific literature on stereotactic radiotherapy for pulmonary metastases.

Background: Stereotactic body radiation therapy (SBRT) is a radiation therapy technique that delivers a high dose of radiation very precisely to an extracranial target, using either a single dose or a small number of fractions. The lung is the main site of metastatic spread for most solid tumors and local treatments have an emerging role, especially in oligometastatic patients. SBRT requires a coordinated team effort between radiation oncologists, medical physicists, radiation therapists and nurses. With this review, we present and analyze the most recent data in terms of clinical results and toxicity that also in the absence of phase III randomized trial allow to reach clinically relevant findings on the cost-benefit balance of stereotactic radiotherapy of lung metastasis (LM).

Methods: In this review, we analyzed the literature data of the last ten years on patients treated with SBRT for lung oligometastasis. We found a number of non-randomized retrospective studies heterogeneous in terms of primary tumour, number of lesions and techniques.

Conclusions: All authors conclude that SBRT represents an effective, safe option, with a low toxicity profile, which improves local control of the disease and the overall survival (OS) of patients with lung metastases. These characteristics together with the convenience of the few treatment sessions make it an excellent alternative to other more invasive therapy. Future randomized studies will enable people to better define the most appropriate dose and fractionation, the most suitable patients in terms of histology of the primary tumors and the best integration with systemic therapies.
\end{abstract}

Keywords: Radiotherapy; stereotactic radiotherapy; pulmonary metastasis; oligometastasis

Received: 21 June 2021; Accepted: 12 August 2021; Published: 30 June 2022.

doi: $10.21037 /$ asj-21-53

View this article at: https://dx.doi.org/10.21037/asj-21-53

\section{Introduction}

The lung is the main site of metastatic spread for most solid tumors and local treatments have an emerging role especially in oligometastatic patients. Surgical resection has been widely used in carefully selected patients (1).

Stereotactic body radiation therapy (SBRT) is an external beam radiation therapy technique that very precisely deliver a high dose of radiation to an extracranial target within

$\wedge$ ORCID: 0000-0002-7280-5698. 
the body, using either a single dose or a small number of fractions. Specialized treatment planning results in steep dose gradients beyond the target (2).

The European Organization for Research and Treatment of Cancer (EORTC) Lung Cancer Group agrees that the definition of oligometastatic disease (OMD) is appropriate when a radical treatment is technically feasible. The potential toxicity should be acceptable, with all sites being amenable to a local treatment that may modify the course of the disease and being an opportunity for long-term disease control.

Extensive diagnostic evaluation including positron emission tomography/computed tomography (PET/ $\mathrm{CT}$ ) and brain imaging, are necessary to define a patient as oligometastatic (3). A maximum of five metastases and three organs has been proposed (not including mediastinal lymph nodes). The presence of diffuse serosal metastases (meningeal, pericardial, pleural, and mesenteric) or bone marrow involvement are excluded from this definition.

In a recently ESTRO-ASTRO published consensus document has been given a new definition for OMD that is independent of the type and histology of primary tumor and of the site of metastases but includes only $1-5$ treatable lesions with or without a controlled primary site of disease (4). Determinants, however, are the number of lesions (regardless of the localization) and the radical purpose of the therapeutic intent.

Diagnostic imaging should be performed using any modalities adequate to scan and identify any metastases detecting also small lesions. The most common are computed tomography (CT) scan of the chest/abdomen/ pelvis, magnetic resonance imaging (MRI) of the brain or spine and whole body PET/CT. SBRT allowing precise delivery of high radiation dose, defined as "ablative dose", with maximum sparing of normal tissue has emerged as a safe and efficacious treatment modality for selected patients with pulmonary metastases $(\mathrm{PM})(5,6)$.

In order to consider the dose effective and therefore "radical" in SBRT, using the concept of BED (biologically effective dose), a minimum $\operatorname{BED}(\alpha / \beta=10)$ of 100 gray (Gy) is conventionally considered necessary in order to achieve local control of OMD. BED is the expression of the combination of dose per fraction, total dose and tissue characteristics ( $\alpha / \beta$ ratio of the specific tissue). Therefore is a measure of the true biological dose delivered and is commonly used to compute and compare the iso-effective dose (7). $\alpha / \beta$ ratio represent the intrinsic radio sensitivity of the irradiated tissue: most tumors exhibit an high $\alpha / \beta$ ratios (e.g., $\alpha / \beta=10$ Gy is commonly used) (8).
The radiobiological advantage of SBRT depend on the shorter treatment time and the high dose per fraction compared to conventional radiotherapy, preventing the cellular repopulation that can occur during a longer radiation therapy course (9).

The best approach to cancer patients is multidisciplinary with the involvement of the different professional figures such as surgeons, medical oncologists, radiation oncologists, radiologists, pathologists and specialist in nuclear medicine. In specific situation, other professional figures are involved, such as psychologists, nutritionists and physiatrists, in order to adequately identify the individual clinical scenario and offer the most appropriate treatment, taking into account patient and disease characteristics, clinical history and previous treatments. SBRT requires a coordinated team effort between radiation oncologists, medical physicist, radiation therapists and nurses (5).

The procedure starts with the CT simulation of the immobilized patient in order to identify the target volume and the nearby normal organs that should receive the minimum dose, named organ at risk (OAR), and to study the respiratory movement. On the CT simulation images, with the aid of dedicated software, the radiation oncologist defines the target volume and OAR and prescribes the radiation dose. The medical physicist prepares the treatment plan and refine it with the radiation oncologist that ultimately give his approval. The first day of the treatment, all that has been previously planned is verified with the patient at the linear accelerator and the treatment is delivered. The essential point of the process is the precise daily reproducibility of the treatment. This is achieved with a compromise between a tight fitting and a comfortable immobilization of the patient often achieved with the creation of a customized thermoplastic masks, but also by the motion management and by the use of image-guided verification systems.

All these measures enable to reduce intrafraction/ interfraction variability, therefore the safety margins conventionally given to the target volume could be decreased. This enables to reduce the irradiated volume of OAR ultimately allowing the increase of the prescribed dose.

A PET-FDG simulation can be associated to the CTsimulation with the same immobilization system taking advantage of metabolic images in order to obtain a better definition of the target. Moreover, inoculating contrast media to the patient during the CT simulation, which is normally performed without it, help in selected cases as perimediastinal lesions, a finest identification of the target. 


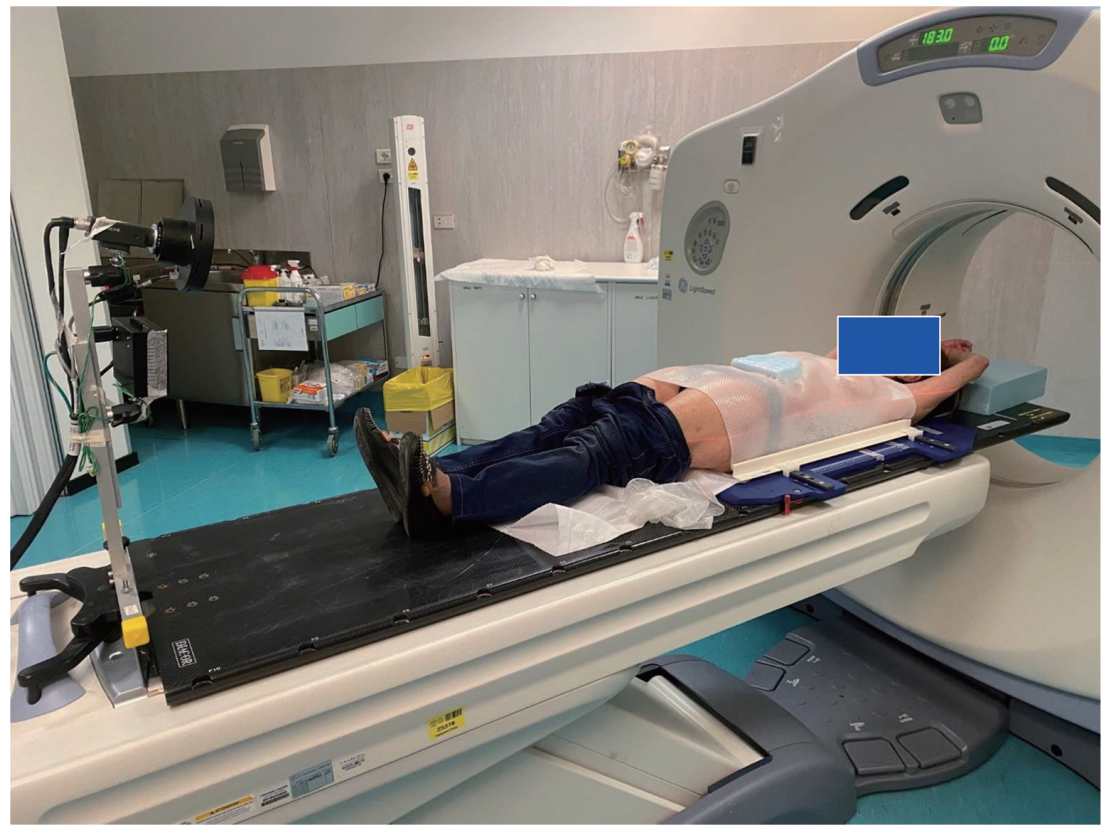

Figure 1 Patient immobilized with thermoplastic mask and diaphragmatic frame for abdominal compression built according to the patient's rib arch by the radiation therapists. The figure shows the respiratory gating system adopted in our department. Gating is a system that tracks a patient's normal respiratory cycle with a chest/abdomen marker camera. This image is published with the patient's consent.

In order to clear up the procedure described above; we report here a graphic depiction of the sequence of event that led to stereotaxic radiotherapy treatment performed at the Radiotherapy Department of "Istituti Clinici Scientifici Maugeri IRCCS" of Pavia. Initially the anatomic region of interest is scanned with the CT simulator while the motion of the markers placed on chest and abdomen is tracked with an infrared camera (Figure 1). The images are analyzed using four dimensions (4D) software (the fourth dimension is time) to accurately correlate the shift of the tumor with the breathing motions. The target volume will be defined by the envelope of all different position of the lesion during breathing motion (Figure 2).

With this review, we present and analyze the most recent data in terms of clinical results and toxicity published in the literature on the topic of stereotactic radiotherapy of lung metastasis (LM). We present the following article in accordance with the Narrative Review reporting checklist (available at https://asj.amegroups.com/article/ view/10.21037/asj-21-53/rc).

\section{Methods}

In order to collect and analyze the most significant papers of the last ten years starting from 2011 forward, we carried out a literature search using the terms "stereotactic body radiotherapy" and "pulmonary oligo metastases".

We selected 31 articles considering the following points: originality of the study, appropriate prescribed doses excluding those with only palliative intent, employed fractionation (1 to 10 fractions) and clinical outcomes.

The analysis showed two differences in the treatment approach in terms of the number of fractions and technique: single (Table 1) vs. multiple fractions (Table 2) and conformal three-dimension (3D) techniques vs. volumetric modulated arc therapy (VMAT).

\section{Discussion}

The pattern of care of PM with stereotaxic radiotherapy vary in doses and number of fractions. We begin by discussing the experiences in single fraction moving then on those in multiple fractions.

We analyzed the literature of the last 10 years, starting in 2011. All studies are retrospective analysis of patients treated in the early years with conformal 3D radiotherapy and more recently with VMAT.

The group of Ricardi et al. (6) gave an important 


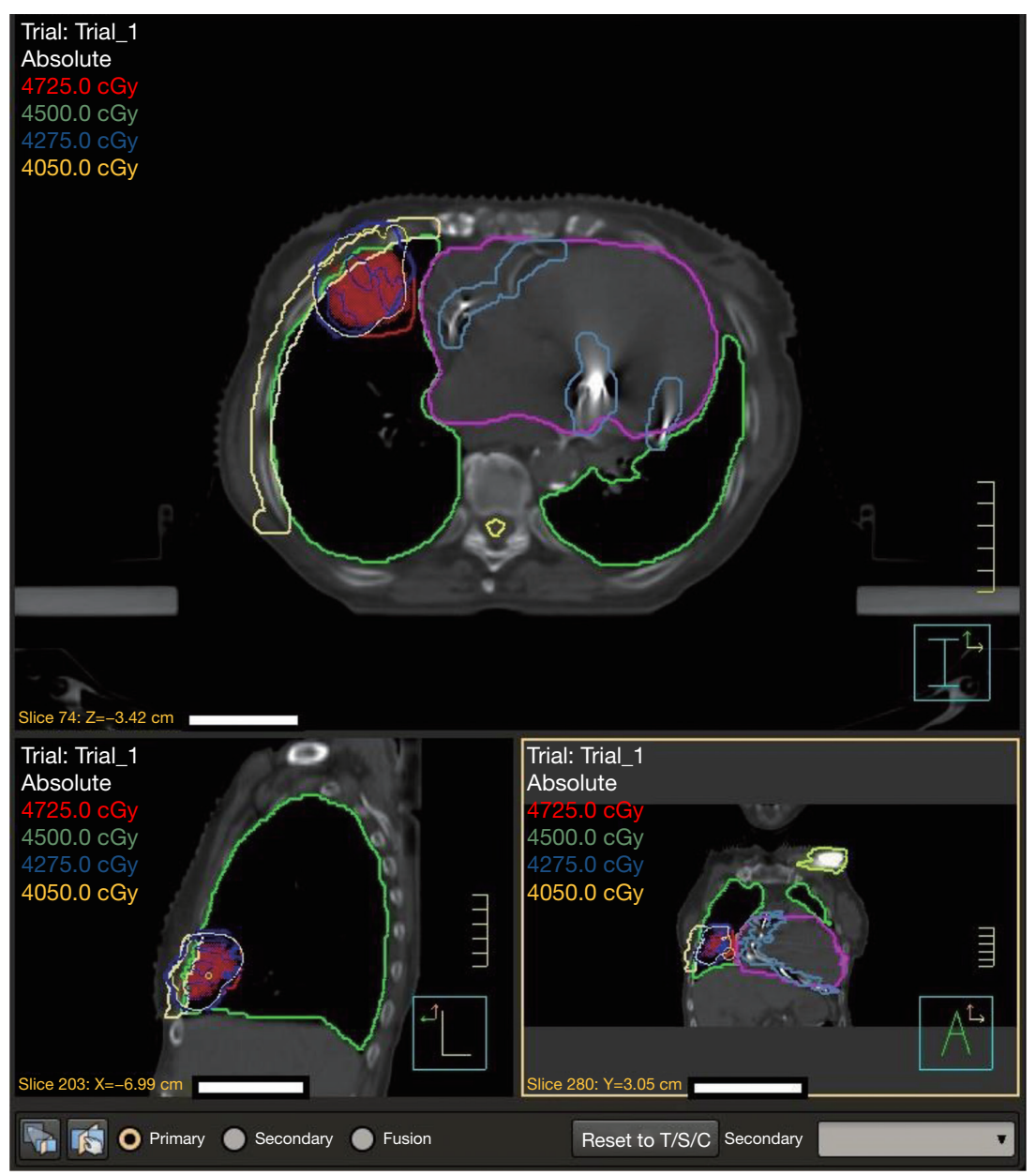

Figure 2 Stereotactic treatment plan with isodose distribution on a lesion of the right lobe on coronal, sagittal and axial plane of the CT simulation.

contribution in this field publishing in 2012 a study on 77 metastases, 51 of which treated with 26 Gy single fraction and 26 with 45 Gy in 3 fractions. Results at two years were excellent in terms of local control (LC), and overall survival (OS) in a context of very low rate of grade 3 (G3) toxicity. These results were confirmed with an update published two years later by Filippi et al. (11) that reported the outcome of treatment of 90 metastases on 67 patients. The primary tumors were various but the vast majority were colorectal cancer. The prescribed dose was $26 \mathrm{~Gy}$ in single fraction. Two-year LC and OS were comparable to the older study. This study is appealing for the uniformity of the dose prescribed, on a relevant number of patients with an adequate follow up (FU) for a preliminary estimate of LC and OS.

The same author in 2016 (15) published data on 43 lesions mostly treated with single fraction as shown in Table 1 .
LC and OS were good, $86 \%$ and $77 \%$ respectively with no G3 toxicity. The aim of the study was also to compare the outcome of stereotactic radiotherapy with surgery. Even with all the limits of the retrospective observational analysis and the difference in the samples size, 142 Surgery vs. 43 SBRT, the author concludes that OS at 2 years are comparable in the two groups.

Osti et al. in 2013 (10) conducted a study on 66 patients, 103 metastases from different primary (most were from lung, breast and rectal cancers). At 1 and 2 years LC were $89.1 \%$ and $82.1 \%$, OS $76.4 \%$ and $31.2 \%$, cancer-specific survival (CSS) $78.5 \%$ and $35.4 \%$, progression-free survival (PFS) $53.9 \%$ and $22 \%$, respectively. Toxicity profiles was good, with two Grade 3 toxicity (pneumonitis). The same author in 2018 (16) published the data on 166 lesions, mostly from lung and colorectal primary tumor, treated 
Table 1 Characteristics of the selected studies in single fraction studies.

\begin{tabular}{|c|c|c|c|c|c|c|c|}
\hline Author, year & $\begin{array}{c}\text { No. of } \\
\text { patients }\end{array}$ & $\begin{array}{l}\text { No. of } \\
\text { lung } \\
\text { lesions }\end{array}$ & Primary site & Dose & Local control & Overall survival & Toxicity, $\mathrm{G} \geq 3$ \\
\hline $\begin{array}{l}\text { Osti et al. (10), } \\
2013\end{array}$ & 66 & 103 & $\begin{array}{l}\text { All (mostly lung, } \\
\text { rectal and breast) }\end{array}$ & $\begin{array}{l}23 \text { Gy } 1 / \text { fr (central); } \\
30 \text { Gy } 1 / \text { fr (peripheral) }\end{array}$ & $2-y 82 \%$ & $2-y 31 \%$ & $3 \%$ G3 pneumonitis \\
\hline $\begin{array}{l}\text { Wang et al. (12), } \\
2015\end{array}$ & 95 & 134 & All (mostly lung) & $30-60 \mathrm{~Gy} / 1-5 \mathrm{fr}$ & $2-y 91 \%$ & $2-y 61 \%$ & $3 \%$ G3 pneumonitis \\
\hline $\begin{array}{l}\text { Siva et al. (13), } \\
2015\end{array}$ & 65 & 85 & All & $\begin{array}{l}18-26 \text { Gy/1 fr (41/85); } \\
48-50 \text { Gy/4-7 fr (44/85) }\end{array}$ & $2-y 93 \%$ & $2-y: 71 \%$ & None \\
\hline $\begin{array}{l}\text { Filippi et al. (15), } \\
2016\end{array}$ & 28 & 43 & Colorectal & $\begin{array}{l}26 \text { Gy/1 fr (31/43); } \\
25 \text { Gy/3 fr (8/43); } \\
55-60 \text { Gy/8-10 fr (4/43) }\end{array}$ & $\begin{array}{l}\text { Median FU } 27-\mathrm{m} \text { : local } \\
\text { recurrence } 21 \%\end{array}$ & $2-y 77 \%$ & None \\
\hline $\begin{array}{l}\text { Osti et al. (16), } \\
2018\end{array}$ & 129 & 166 & $\begin{array}{l}\text { All (mostly lung } \\
\text { and colorectal) }\end{array}$ & $30 \mathrm{~Gy} / 1 \mathrm{fr}$ & $\begin{array}{l}\text { LPFS: } \\
\text { 3-y } 80.1 \% \text {; } \\
5-y 79.2 \%\end{array}$ & $\begin{array}{l}3-y \text { 50.7\%; } \\
5-y 37.9 \%\end{array}$ & $\begin{array}{l}3.6 \% \text { G3 pneumonitis; } \\
1.2 \% \text { G5 pneumonitis; } \\
7.4 \% \text { G3 lung fibrosis; } \\
1.3 \% \text { rib fracture }\end{array}$ \\
\hline $\begin{array}{l}\text { Kalinauskaite } \\
\text { et al. (17), } 2020\end{array}$ & 52 & 94 & $\begin{array}{l}\text { All (mostly } \\
\text { colorectal) }\end{array}$ & $\begin{array}{l}22-8 \text { Gy/1-5 fr } \\
\text { (mostly } 24 \text { Gy/1 fr) }\end{array}$ & $\begin{array}{l}1-y \text { and } 2-y \text { for SFRS } \\
\text { vs. fSBRT: } 89 \% \text { and } \\
83 \% \text { vs. } 75 \% \text { and } 59 \% \text {, } \\
\text { respectively }\end{array}$ & $\begin{array}{l}1-y \text { 84\%; } \\
2-y 71 \%\end{array}$ & None \\
\hline
\end{tabular}

fr, frequency; y, year; FU, follow up; m, month; LPFS, local relapse-free survival; SFRS, single fraction radiosurgery; fSBRT, fractionated stereotactic body radiotherapy.

with 30 Gy single fraction. The 3 and 5 years local relapsefree survival (LPFS) were $80.1 \%$ and $79.2 \%$ (median not reached), respectively. One hundred and forty-eight patients were evaluated for late toxicity, see Table 1. The 3- and 5 -years OS were $50.7 \%$ and $37.9 \%$, respectively. The data of these two studies are interesting for the homogeneity of the dose delivered and certainly constitute a home base for future study on the radiosurgical approach to pulmonary oligometastases.

Wang et al. (12) in 2015 published the results of stereotactic radiotherapy of 134 lung lesions of varying primary tumors, the majority lung cancer. The doses were $30-60$ Gy in 1-5 fractions. G3 toxicities were low (3\% of G3 pneumonitis). At two years, LC and OS were $91 \%$ and $61 \%$, respectively.

Also in 2015, Siva et al. (13) published a study on $85 \mathrm{LM}$ of varying primary tumors. They reported a variety of approaches that included single fraction for 41 of the 85 lesions with a dose between 18 and 26 Gy, and 4 to 7 fractions for 44 of the 85 lesions, dose range between 45 and the 50 Gy. They reported no relevant toxicities with a two-year LC of $93 \%$ and an OS of $72 \%$.

More recently, in 2020, Kalinauskaite et al. (17) searched for prognostic features of better survival outcomes after single fraction radiosurgery (SFRS) and fractionated SBRT (fSBRT) in patients with lung oligometastases. They treated fifty-two patients with SFRS or fSBRT. Median dose to the planning target volume (PTV) for SFRS was 24 Gy (range, 17-26 Gy) compared to 45 Gy (range, 20-60 Gy) in 2-12 fractions for fSBRT. LC and OS at 1 and 2 years were better for SFRS vs. fSBRT. LM treated with SFRS were significantly smaller $(\mathrm{P}=0.001)$. Longer time to first metastasis, good KPS $(<70)$ and N0 predicted better OS.

Our review aim to describe the role of SBRT even in 
Table 2 Characteristics of the selected studies in multiple fraction studies

\begin{tabular}{|c|c|c|c|c|c|c|c|}
\hline Author, year & $\begin{array}{l}\text { No. of } \\
\text { patients }\end{array}$ & $\begin{array}{l}\text { No. of } \\
\text { lung } \\
\text { lesions }\end{array}$ & Primary site & Dose & Local control & Overall survival & Toxicity, $\mathrm{G} \geq 3$ \\
\hline $\begin{array}{l}\text { Oh et al. (19), } \\
2012\end{array}$ & 57 & 67 & All (mostly lung) & $50-60 \mathrm{~Gy} / 5-4 \mathrm{fr}$ & 3-у $94.5 \%$ & $2-y 60 \%$ & $1 \mathrm{G} 5$ pneumonitis \\
\hline $\begin{array}{l}\text { Baschnagel } \\
\text { et al. (21), } 2013\end{array}$ & 32 & 47 & All & $\begin{array}{l}\text { Various, mostly } 60 \mathrm{~Gy} / 5 \mathrm{fr} \\
(36 / 47)\end{array}$ & $2-y 92 \%$ & $2-y 76 \%$ & 16\% G3 (various) \\
\hline $\begin{array}{l}\text { Soyfer et al. (23), } \\
2014\end{array}$ & 22 & 53 & Sarcoma & $\begin{array}{l}\text { Various, mostly } \\
60 \text { Gy/3 fr (33/53) }\end{array}$ & $\begin{array}{l}\text { Mean 5.1-m: } \\
64 \%(0-10 \mathrm{~mm}) \\
30 \%(11-20 \mathrm{~mm}) \\
6 \%(>20 \mathrm{~mm})\end{array}$ & $5-y 62 \%$ & $5 \%$ pneumonitis \\
\hline $\begin{array}{l}\text { Garcia-Cabezas } \\
\text { et al. (24), } 2015\end{array}$ & 42 & 53 & All (mostly colon) & $\begin{array}{l}60 \text { Gy/5 fr (35/53); } \\
60 \text { Gy/8 fr (11/53); } \\
50 \text { Gy/10 fr (7/53) }\end{array}$ & $2-y 87 \%$ & $2-y 60 \%$ & None \\
\hline $\begin{array}{l}\text { Guckenberger } \\
\text { et al. (28), } 2016\end{array}$ & 397 & 525 & All & Various & $\begin{array}{l}\text { Median FU 16-m: } \\
86.7 \%\end{array}$ & Not reported & Not reported \\
\hline $\begin{array}{l}\text { Lischalk et al. } \\
\text { (29), } 2016\end{array}$ & 20 & $\begin{array}{l}\text { Not } \\
\text { reported }\end{array}$ & All (mostly lung) & $35-40 \mathrm{~Gy} / 5 \mathrm{fr}$ & $2-y 57 \%$ & $2-y 40 \%$ & $\begin{array}{l}\text { 5\% G3 pneumonitis } \\
5 \% \text { G4 atelectasia }\end{array}$ \\
\hline $\begin{array}{l}\text { Baumann et al. } \\
\text { (30), } 2016\end{array}$ & 30 & 39 & Sarcoma & $\begin{array}{l}50 \text { Gy/4-5 fr (32/39); } \\
<50 \text { Gy }(7 / 39)\end{array}$ & $2-y 86 \%$ & $2-y 43 \%$ & None \\
\hline $\begin{array}{l}\text { Rieber et al. (31), } \\
2016\end{array}$ & 700 & $\begin{array}{l}\text { Not } \\
\text { reported }\end{array}$ & All & $\begin{array}{l}\text { Median number of fractions: } \\
\text { 3; Median single doses: } 12.5 \\
\text { Gy (range 3.0-33.0 Gy) }\end{array}$ & $\begin{array}{l}1-y \text { 90.9\%; } \\
2-y 81.2 \%\end{array}$ & $\begin{array}{l}1-y \quad 75.1 \% \\
2-y 54.4 \%\end{array}$ & $\begin{array}{l}6.5 \% \geq \mathrm{G} 2 \text { pneumonitis; } \\
0.2 \% \text { G5 pneumonitis; } \\
3.2 \% \text { other } \geq \mathrm{G} 2+ \\
\text { toxicities }\end{array}$ \\
\hline $\begin{array}{l}\text { Ricco et al. (32), } \\
2017\end{array}$ & 304 & 327 & All & $\begin{array}{l}\text { Median } 50 \text { Gy } \\
/ 3-5 \mathrm{fr}\end{array}$ & $\begin{array}{l}1 \text {-у } 80.4 \% \\
3-y 58.9 \% \\
5-y 46.2 \%\end{array}$ & $\begin{array}{l}1-y 74.1 \% \\
3-y 33.3 \% \\
5-y 21.8 \%\end{array}$ & Not reported \\
\hline $\begin{array}{l}\text { Franceschini } \\
\text { et al. (33), } 2017\end{array}$ & 200 & $\begin{array}{l}\text { Not } \\
\text { reported }\end{array}$ & $\begin{array}{l}\text { All (mostly } \\
\text { colorectal) }\end{array}$ & $30-60$ Gy/1-8 fr & $\begin{array}{l}1-y \text { 91\%; } \\
2 \text {-у } 84.9 \%\end{array}$ & $\begin{array}{l}1 \text {-у } 88.7 \% \\
2-y 65.4 \%\end{array}$ & None \\
\hline
\end{tabular}

Table 2 (continued) 
Table 2 (continued)

\begin{tabular}{|c|c|c|c|c|c|c|c|}
\hline Author & $\begin{array}{c}\text { No. of } \\
\text { patients }\end{array}$ & $\begin{array}{l}\text { No. of } \\
\text { lung } \\
\text { lesions }\end{array}$ & Primary site & Dose & Local control & Overall Survival & Toxicity, $G \geq 3$ \\
\hline $\begin{array}{l}\text { Lindsay et al. } \\
\text { (35), } 2018\end{array}$ & 44 & 117 & Sarcoma & $\begin{array}{l}36-50 \mathrm{~Gy} / 6-10 \mathrm{fr} \\
\text { (mostly } 50 \mathrm{~Gy} / 10 \mathrm{fr} \text { ) }\end{array}$ & $2-y 95 \%$ & $\begin{array}{l}2-y \quad 82 \% \\
5-y 50 \%\end{array}$ & 1 Esophageal stricture \\
\hline $\begin{array}{l}\text { Hörner-Rieber } \\
\text { et al. (36), } 2019\end{array}$ & 301 & 336 & NSCLC & Various & $\begin{array}{l}1-y \text { 91.9\%; } \\
\text { 2-y 82.0\%; } \\
3-y 76.4 \% \\
5-y 70.3 \%\end{array}$ & $\begin{array}{l}1 \text {-y } 80.8 \% \\
2 \text {-y } 62.2 \% \\
\text { 3-y } 48.1 \% \\
\text { 5-y } 28.8 \%\end{array}$ & Not reported \\
\hline $\begin{array}{l}\text { Wegner et al. } \\
(37), 2019\end{array}$ & 44 & 50 & $\begin{array}{l}\text { All (mostly } \\
\text { colorectal) }\end{array}$ & $48 \mathrm{~Gy} / 5 \mathrm{fr}$ & $1-y 82 \%$ & $1-y 66 \%$ & None \\
\hline $\begin{array}{l}\text { Kessel et al. (39), } \\
2020\end{array}$ & 219 & 316 & All & $\begin{array}{l}\text { Various median dose } 35 \text { Gy } \\
\text { and median dose per fraction } \\
8 \text { Gy }\end{array}$ & $\begin{array}{l}1-\text { - } 92 \% ; \\
2-\text {-у } 84 \% ; \\
3-y ~ 78 \% ; \\
4-y ~ 77 \% ; \\
5-y ~ 75 \% ; \\
10-y 75 \%\end{array}$ & $\begin{array}{l}1 \text {-у } 74 \% ; \\
2 \text {-у } 54 \% ; \\
3-y 39 \% ; \\
4-y 29 \% ; \\
\text { 5-у } 26 \% ; \\
10-y 17 \%\end{array}$ & G3 2.9\% \\
\hline
\end{tabular}

fr, frequency; y, year; FU, follow up; m, month; SBRT, stereotactic body radiotherapy; NSCLC, non-small cell lung cancer.

studies in which the treatment was fractionated. Also in these studies the results were satisfactory and the toxicity low. In 2011, Takeda et al. (18) published the results of the treatment of 44 secondary lesions of various primary tumors (mostly colon cancers) after 50 Gy in 5 fractions. Remarkable for this analysis is the difference of LC based on the primary tumor: when colon cancer was the primary, the two-year LC was much lower compared to other primary.

Oh et al. (19) described similar results in his analysis on 67 lesions with lung cancer as predominant primary site. Three-year LC rate was $94.5 \%$, two-year OS $60 \%$, reported toxicity was $13 \%$ for rib fracture and 1 death from pneumonitis.

In 2013, Inoue et al. (20) published data on a larger sample of patients treated for oligo metastases mostly from colorectal cancer. They treated 189 lesions with various fractionation schemes (see Table 2); the most represented in the analysis was 48 Gy/4 fractions. The two-year LC was $80 \%$, OS $47 \%$ and a low toxicity profile.

One preliminary observation that could be drawn from the studies reported above, though conducted on different samples and with different fractionation and doses, is that treating metastases from colorectal cancer achieve lower LC compared to other primary tumors.

In 2014, Navarria et al. (5) published data of treatment outcome of 118 metastases (mostly from colorectal cancer). The total dose prescribed varied according to tumor location and size: $48 \mathrm{~Gy}$ in 4 fractions for peripheral lesions, the schedule adopted most frequently, 60 Gy in 8 fractions for central lesions and 3 fractions for peripheral lesions with diameter $\leq 2 \mathrm{~cm}$. LC at 1, 2 and 3 years was $95 \%, 89 \%$ and $89 \%$ respectively. OS at 1,2 and 3 years was $84.1 \%, 73 \%$ and $73 \%$ respectively. No major pulmonary toxicity, chest pain or rib fracture occurred.

Three years later the same Institution published the results of further experiences. Franceschini et al. (33) described the stereotactic treatment of 200 patients with a predominance of colorectal cancer ( $49.5 \%$ of the cases) as primary tumor. This experience with a large number of patients with metastases from colorectal carcinoma confirmed his "radio-resistant" trait negatively affecting LC.

Also, the analysis of AoKi et al. (27) support this hypothesis. They report of 76 oligo-recurrences in the 
lungs treated with SBRT from various primary sites. The median SBRT dose was 50 Gy (range, 45-60 Gy) given in a median of five (range, 5-9) fractions. Oligo-recurrence from colorectal cancer had worse outcomes for LC and DFS compared with those of other primary cancer sites.

In order to obtain more reliable information to guide the choice of the most appropriate therapy, is of great value the availability of study not only with well selected patient but also highly homogeneous in term of histology of the primary tumor. For this purpose there are two interesting study, by Baumann et al. (30) and by Lindsay et al. (35) both targeting LM only from sarcoma. The most frequently prescribed doses were $50 \mathrm{~Gy}$ in 4-5 fractions for the first and $50 \mathrm{~Gy}$ in 10 fractions for the latter. The two-year LC was $86 \%$ for the first and $95 \%$ for the second.

In 2019, Hörner-Rieber et al. (36) published a multicenter study on a large number of oligo metastatic lung lesions ( $\mathrm{n}=301)$ from non-small cell lung cancer (NSCLC) treated in 24 different German and Swiss centers between 1997 and 2017. The number and size of fractions were tailored to tumor size and location (peripheral vs. central). The authors report a BED range at isocenter of 128.2 Gy (37.5-323.4 Gy) for all PM with a difference between patients without an early progression 118.2 Gy (50.7-173.1 Gy) and with early progression 117.0 Gy (54.0-189.0 Gy). The primary value of the study is in the homogeneity of the sample in term of primary tumor, all NSCLC. At different time point of FU: 1-, 2-, 3-, and 5 -year, LC was $91.9 \%, 82.0 \%, 76.4 \%$, and $70.3 \%$, respectively and OS was $80.8 \%, 62.2 \%, 48.1 \%$ and $28.8 \%$ respectively. This multi-institutional patterns-of-care analysis confirmed favorable LC and promising OS of SBRT for PM in patients with NSCLC.

A recent study on 316 metastases from various primary tumors by Kerstin A. Kessel et al. (39) confirms the promising role of SBRT in terms of LC and OS even with a long FU. They reported a low rate of severe side effects. These data confirm the strength of SBRT as therapeutic option and how it is competitive with more invasive treatment.

\section{Summary}

From our literature analysis, we can summarize:

* The ideal candidate for SBRT of lung metastases with curative intent is the oligometastatic patient according to the ESTRO/ASTRO definition.

* The patient management should be multidisciplinary, in highly specialized cancer center, with the involvement of the different professional figures such as surgeons, medical oncologists, radiation oncologists, radiologists, pathologists and specialist in nuclear medicine.

* Patient's performance status should be preliminarily evaluated in order to select only those able to collaborate to a correct planning and delivery of the treatment.

* When planning the dose to be administered as effective and therefore "radical", lesions should receive a minimum total BED of $100 \mathrm{~Gy}$.

* The stereotactic technique, should allow the delivery the high dose to the target with a rapid dose fall off toward the OAR, particularly the intact lungs parenchyma.

* Each treatment fraction should be accurately monitored with all the equipment available to verify the precise implementation of what has been planned via the IGRT tools.

* All authors concludes that SBRT for pulmonary oligo metastases is safe and effective, with approximately $80 \%$ local control rates.

* Some hystotipes appear to respond less to the therapy such as metastases from colorectal, breast, pulmonary cancer and sarcomas. This assertion reflects a common feeling among the authors but is not supported by evidence from randomized studies on each primary tumor's histology.

* To date SBRT represents an alternative and competitive option for the cure of patients with oligo metastatic lung disease other than those unsuitable or refusing surgery.

* Future randomized studies will serve to better define the most appropriate dose and fractionation, the most suitable patients in terms of histology of the primary tumors and the best integration with systemic therapies.

\section{Acknowledgments}

Funding: None.

\section{Footnote}

Provenance and Peer Review: This article was commissioned by the Guest Editors (Davide Tosi, Alessandro Palleschi and Paolo Mendogni) for the series "Management and 
Treatment of Lung Metastases" published in AME Surgical fournal. The article has undergone external peer review.

Reporting Checklist: The authors have completed the Narrative Review reporting checklist. Available at https:// asj.amegroups.com/article/view/10.21037/asj-21-53/rc

Peer Review File: Available at https://asj.amegroups.com/ article/view/10.21037/asj-21-53/prf

Conflicts of Interest: All authors have completed the ICMJE uniform disclosure form (available at https://asj.amegroups. com/article/view/10.21037/asj-21-53/coif). The series "Management and Treatment of Lung Metastases" was commissioned by the editorial office without any funding or sponsorship. The authors have no other conflicts of interest to declare.

Ethical Statement: The authors are accountable for all aspects of the work in ensuring that questions related to the accuracy or integrity of any part of the work are appropriately investigated and resolved.

Open Access Statement: This is an Open Access article distributed in accordance with the Creative Commons Attribution-NonCommercial-NoDerivs 4.0 International License (CC BY-NC-ND 4.0), which permits the noncommercial replication and distribution of the article with the strict proviso that no changes or edits are made and the original work is properly cited (including links to both the formal publication through the relevant DOI and the license). See: https://creativecommons.org/licenses/by-nc-nd/4.0/.

\section{References}

1. Pastorino U, Buyse M, Friedel G, et al. Long-term results of lung metastasectomy: prognostic analyses based on 5206 cases. J Thorac Cardiovasc Surg 1997;113:37-49.

2. Potters L, Kavanagh B, Galvin JM, et al. American Society for Therapeutic Radiology and Oncology (ASTRO) and American College of Radiology (ACR) practice guideline for the performance of stereotactic body radiation therapy. Int J Radiat Oncol Biol Phys 2010;76:326-32.

3. European Society for Radiotherapy and Oncology and European Organisation for Research and Treatment of Cancer. MA25.02 Searching for a Definition of Synchronous Oligometastatic (sOMD)-NSCLC: A Consensus from Thoracic Oncology Experts. J Thorac
Oncol 2018;13:S446.

4. Lievens Y, Guckenberger M, Gomez D, et al. Defining oligometastatic disease from a radiation oncology perspective: An ESTRO-ASTRO consensus document. Radiother Oncol 2020;148:157-66.

5. Navarria P, Ascolese AM, Tomatis S, et al. Stereotactic body radiotherapy (sbrt) in lung oligometastatic patients: role of local treatments. Radiat Oncol 2014;9:91.

6. Ricardi U, Filippi AR, Guarneri A, et al. Stereotactic body radiation therapy for lung metastases. Lung Cancer 2012;75:77-81.

7. Bentzen SM, Dörr W, Gahbauer R, et al. Bioeffect modeling and equieffective dose concepts in radiation oncology--terminology, quantities and units. Radiother Oncol 2012;105:266-8.

8. van Leeuwen CM, Oei AL, Crezee J, et al. The alfa and beta of tumours: a review of parameters of the linearquadratic model, derived from clinical radiotherapy studies. Radiat Oncol 2018;13:96.

9. Wang JZ, Huang Z, Lo SS, et al. A generalized linearquadratic model for radiosurgery, stereotactic body radiation therapy, and high-dose rate brachytherapy. Sci Transl Med 2010;2:39ra48.

10. Osti MF, Carnevale A, Valeriani M, et al. Clinical outcomes of single dose stereotactic radiotherapy for lung metastases. Clin Lung Cancer 2013;14:699-703.

11. Filippi AR, Badellino S, Guarneri A, et al. Outcomes of single fraction stereotactic ablative radiotherapy for lung metastases. Technol Cancer Res Treat 2014;13:37-45.

12. Wang Z, Kong QT, Li J, et al. Clinical outcomes of cyberknife stereotactic radiosurgery for lung metastases. J Thorac Dis 2015;7:407-12.

13. Siva S, Kirby K, Caine H, et al. Comparison of Singlefraction and Multi-fraction Stereotactic Radiotherapy for Patients with 18F-fluorodeoxyglucose Positron Emission Tomography-staged Pulmonary Oligometastases. Clin Oncol (R Coll Radiol) 2015;27:353-61.

14. Davis JN, Medbery C, Sharma S, et al. Stereotactic body radiotherapy for centrally located early-stage non-small cell lung cancer or lung metastases from the RSSearch(®) patient registry. Radiat Oncol 2015;10:113.

15. Filippi AR, Guerrera F, Badellino S, et al. Exploratory Analysis on Overall Survival after Either Surgery or Stereotactic Radiotherapy for Lung Oligometastases from Colorectal Cancer. Clin Oncol (R Coll Radiol) 2016;28:505-12.

16. Osti MF, Agolli L, Valeriani M, et al. 30 Gy single dose stereotactic body radiation therapy (SBRT): Report 
on outcome in a large series of patients with lung oligometastatic disease. Lung Cancer 2018;122:165-70.

17. Kalinauskaite GG, Tinhofer II, Kufeld MM, et al. Radiosurgery and fractionated stereotactic body radiotherapy for patients with lung oligometastases. BMC Cancer 2020;20:404.

18. Takeda A, Kunieda E, Ohashi T, et al. Stereotactic body radiotherapy (SBRT) for oligometastatic lung tumors from colorectal cancer and other primary cancers in comparison with primary lung cancer. Radiother Oncol 2011;101:255-9.

19. Oh D, Ahn YC, Seo JM, et al. Potentially curative stereotactic body radiation therapy (SBRT) for single or oligometastasis to the lung. Acta Oncol 2012;51:596-602.

20. Inoue T, Oh RJ, Shiomi H, et al. Stereotactic body radiotherapy for pulmonary metastases. Prognostic factors and adverse respiratory events. Strahlenther Onkol 2013;189:285-92.

21. Baschnagel AM, Mangona VS, Robertson JM, et al. Lung metastases treated with image-guided stereotactic body radiation therapy. Clin Oncol (R Coll Radiol) 2013;25:236-41.

22. Widder J, Klinkenberg TJ, Ubbels JF, et al. Pulmonary oligometastases: metastasectomy or stereotactic ablative radiotherapy? Radiother Oncol 2013;107:409-13.

23. Soyfer V, Corn BW, Shtraus N, et al. Single-institution Experience of SBRT for Lung Metastases in Sarcoma Patients. Am J Clin Oncol 2017;40:83-5.

24. García-Cabezas S, Bueno C, Rivin E, et al. Lung metastases in oligometastatic patients: outcome with stereotactic body radiation therapy (SBRT). Clin Transl Oncol 2015;17:668-72.

25. Qiu H, Katz AW, Chowdhry AK, et al. Stereotactic Body Radiotherapy for Lung Metastases from Colorectal Cancer: Prognostic Factors for Disease Control and Survival. Am J Clin Oncol 2018;41:53-8.

26. Jung J, Song SY, Kim JH, et al. Clinical efficacy of stereotactic ablative radiotherapy for lung metastases arising from colorectal cancer. Radiat Oncol 2015;10:238.

27. Aoki M, Hatayama Y, Kawaguchi H, et al. Stereotactic body radiotherapy for lung metastases as oligo-recurrence: a single institutional study. J Radiat Res 2016;57:55-61.

28. Guckenberger M, Klement RJ, Allgäuer M, et al. Local tumor control probability modeling of primary and secondary lung tumors in stereotactic body radiotherapy. Radiother Oncol 2016;118:485-91.
29. Lischalk JW, Malik RM, Collins SP, et al. Stereotactic body radiotherapy (SBRT) for high-risk central pulmonary metastases. Radiat Oncol 2016;11:28.

30. Baumann BC, Nagda SN, Kolker JD, et al. Efficacy and safety of stereotactic body radiation therapy for the treatment of pulmonary metastases from sarcoma: A potential alternative to resection. J Surg Oncol 2016;114:65-9.

31. Rieber J, Streblow J, Uhlmann L, et al. Stereotactic body radiotherapy (SBRT) for medically inoperable lung metastases-A pooled analysis of the German working group "stereotactic radiotherapy". Lung Cancer 2016;97:51-8.

32. Ricco A, Davis J, Rate W, et al. Lung metastases treated with stereotactic body radiotherapy: the RSSearch ${ }^{\circledR}$ patient Registry's experience. Radiat Oncol 2017;12:35.

33. Franceschini D, Cozzi L, De Rose F, et al. Role of stereotactic body radiation therapy for lung metastases from radio-resistant primary tumours. J Cancer Res Clin Oncol 2017;143:1293-9.

34. Mazzola R, Fersino S, Ferrera G, et al. Stereotactic body radiotherapy for lung oligometastases impacts on systemic treatment-free survival: a cohort study. Med Oncol 2018;35:121.

35. Lindsay AD, Haupt EE, Chan CM, et al. Treatment of Sarcoma Lung Metastases with Stereotactic Body Radiotherapy. Sarcoma 2018;2018:9132359.

36. Hörner-Rieber J, Bernhardt D, Blanck O, et al. Long-term Follow-up and Patterns of Recurrence of Patients With Oligometastatic NSCLC Treated With Pulmonary SBRT. Clin Lung Cancer 2019;20:e667-77.

37. Wegner RE, Abel S, Hasan S, et al. Stereotactic Body Radiotherapy (SBRT) for Oligometastatic Lung Nodules: A Single Institution Series. Front Oncol 2019;9:334.

38. Berkovic P, Gulyban A, Defraene G, et al. Stereotactic robotic body radiotherapy for patients with oligorecurrent pulmonary metastases. BMC Cancer 2020;20:402.

39. Kessel KA, Grosser RCE, Kraus KM, et al. Stereotactic body radiotherapy (SBRT) in patients with lung metastases - prognostic factors and long-term survival using patient self-reported outcome (PRO). BMC Cancer 2020;20:442.

doi: 10.21037/asj-21-53

Cite this article as: Tozzi A, Meaglia I, Trapani L, Ivaldi GB. Stereotactic radiotherapy for the treatment of pulmonary metastases: a narrative review. AME Surg J 2022;2:12. 